\title{
ARTIKELEN
}

\section{Iedereen kent iedereen}

\section{De invloed van kleinschaligheid en informele politiek op bestuur in Caribisch Nederland*}

\author{
Wouter Veenendaal ${ }^{* *}$
}

\section{Inleiding}

Op 10 oktober 2010 werden de Nederlandse Antillen ontmanteld en verkreeg elk van de vijf eilanden waaruit dit non-soevereine land bestond een nieuwe politieke status. De twee eilanden met het grootste aantal inwoners, Curaçao en Sint-Maarten, werden autonome landen binnen het Koninkrijk der Nederlanden, een status die Aruba al sinds 1986 heeft. De drie in demografisch opzicht kleinste eilanden, Bonaire, Sint-Eustatius en Saba (de BES-eilanden, sinds 2010 formeel aangeduid als Caribisch Nederland), werden als openbare lichamen in het Nederlandse staatsbestel geïntegreerd, en werden daarmee staatsrechtelijk onderdeel van Europees Nederland. Op deze eilanden werd de Antilliaanse wetgeving geleidelijk vervangen door de Nederlandse, werd de Antilliaanse gulden vervangen door de Amerikaanse dollar, en verkreeg de Nederlandse rijksoverheid de uitvoerende macht op de belangrijkste beleidsterreinen. De lokale overheid van de eilanden werd ingericht op basis van het bestuursmodel dat in Nederlandse gemeenten gebruikt wordt, en om deze reden worden de eilanden vaak bijzondere gemeenten van Nederland genoemd. ${ }^{1}$ Naast de lokale overheid (het openbaar lichaam) is de rijksoverheid op de drie eilanden vertegenwoordigd door de Rijksdienst Caribisch Nederland (RCN), een shared service organisatie waarbinnen de Nederlandse ministeries samenwerken. Ten slotte werd de functie van Rijksvertegenwoordiger in het leven geroepen, die fungeert als bestuurlijke schakel tussen de openbare lichamen en Den Haag, en toeziet op goed bestuur in Caribisch Nederland (Oostindie \& Klinkers, 2012).

Uit een evaluatie die in opdracht van de Nederlandse regering in 2015 werd verricht, blijkt dat deze hervormingen vijf jaar na dato grotendeels niet het beoogde resultaat hebben gehad (Spies e.a., 2015). De armoede op de eilanden is de afgelopen jaren gegroeid, en er is weerstand tegen de sterk toegenomen Nederlandse dominantie. Inwoners van de eilanden zijn ontevreden over de stijgende prijzen en de dalende koopkracht, en over de ongelijke invoering van Nederlandse wetgeving (wel het homohuwelijk, maar geen gelijke sociale voorzieningen). Veel

\footnotetext{
* Dit onderzoek is gefinancierd door de Nederlandse Organisatie voor Wetenschappelijk Onderzoek (NWO), projectnummer 858.14.012.

** Dr. Wouter Veenendaal is werkzaam als universitair docent bij het Instituut Politieke Wetenschap van de Universiteit Leiden.
} 
eilandbewoners betreuren de verminderde autonomie van hun eiland en het feit dat Nederland vrijwel unilateraal het beleid op de eilanden kan uitzetten. Uit een apart onderzoek naar de werking van de nieuwe bestuurlijke structuur blijkt bovendien dat het nieuwe bestuursmodel van de openbare lichamen niet effectief functioneert en dat de nieuwe bestuurlijke structuur niet in staat is geweest om de meeste bestuurlijke uitdagingen die voor 10 oktober 2010 bestonden te elimineren (Nauta, 2015, 159; zie Mamadouh \& Nauta, 2002). In de zomer van 2015 werd het eiland Sint-Eustatius vanwege bestuurlijk disfunctioneren zelfs onder toezicht van het Rijk gesteld, waardoor het eilandbestuur geen nieuwe financiële verplichtingen meer aan mocht gaan. Op Bonaire en Sint-Eustatius zorgen voortdurend wisselende bestuurscoalities voor veel instabiliteit, wat ten koste gaat van de bestuurskracht. Een opvallend contrast wordt gevormd door Saba, dat juist al decennialang bestuurd wordt door dezelfde partij. Over het geheel genomen hebben de hervormingen van 2010 echter niet geleid tot een noemenswaardige verbetering van het bestuur in Caribisch Nederland.

In dit artikel worden de oorzaken van de bestuurlijke problemen in Caribisch Nederland in kaart gebracht, en wordt op basis daarvan bekeken waarom de nieuwe bestuurlijke structuur (nog) niet tot verbeteringen in de bestuurskracht heeft geleid. De analyse is gebaseerd op uitgebreid veldonderzoek op elk van de drie eilanden van Caribisch Nederland, dat voornamelijk bestond uit semigestructureerde diepte-interviews met lokale politici en politiek betrokkenen. Achtereenvolgens werden interviews gehouden op Sint-Eustatius (in juni 2015), Saba (januari 2016) en Bonaire (juni-juli 2016). De interviewrespondenten werden geselecteerd met als doel om zo veel mogelijk variatie in politieke standpunten en achtergronden te verkrijgen. Een complete geanonimiseerde lijst van respondenten kan worden gevonden in de bijlage van dit artikel. ${ }^{2}$

$\mathrm{Na}$ een korte bespreking van de relevante literatuur over de effecten van kleinschaligheid op politiek, democratie en bestuur zal in dit artikel eerst worden besproken hoe kleinschaligheid en de politieke cultuur van de postkoloniale Cariben de kwaliteit van het bestuur in Caribisch Nederland hebben beïnvloed. Vervolgens zal worden aangetoond hoe deze factoren zich verhouden tot het in 2010 geïntroduceerde bestuursmodel, en besproken zal worden waarom dit bestuursmodel in Caribisch Nederland vooralsnog niet tot de gewenste verbetering van bestuur heeft geleid. Hierbij zal vooral worden ingegaan op de verhouding tussen formele politieke instituties en de informele politieke praktijk op de eilanden. Ten slotte zullen een aantal opmerkelijke verschillen tussen de drie eilanden van Caribisch Nederland worden besproken, op basis waarvan verklaard kan worden waarom het bestuur van Saba relatief goed functioneert, terwijl de bestuurlijke problemen op Sint-Eustatius verhoudingsgewijs het grootste zijn. Het artikel wordt afgesloten met een conclusie, waarin de implicaties van deze analyse voor de bredere wetenschappelijke literatuur over goed bestuur in kleine eilandsamenlevingen aan de orde zullen komen. 


\section{Kleinschaligheid en de verhouding tussen formele en informele politiek}

De wetenschappelijke literatuur over de politieke effecten van kleinschaligheid is lange tijd gedomineerd door de observatie dat kleine staten significant vaker een democratisch politiek systeem hebben dan grote staten (Diamond \& Tsalik, 1999; Ott, 2000; Anckar, 2002; Srebrnik, 2004). De verklaring voor dit verband wordt vaak gezocht in de werken van de klassieke Griekse filosofen en de denkers van de Verlichting, die betoogden dat kleinschalige samenlevingen worden gekenmerkt door meer sociale cohesie, een grotere betrokkenheid van burgers bij het bestuur, en meer ruimte voor individuele vrijheden. In de jaren zeventig en tachtig van de vorige eeuw argumenteerden onder meer Dahl en Tufte (1973), Lijphart (1977) en Katzenstein (1985) dat kleine samenlevingen homogener en harmonieuzer zijn, waardoor zij een betere voedingsbodem bieden voor democratische ontwikkeling en consensuspolitiek. Verder wordt verondersteld dat de geringe afstand tussen burgers en politici zou zorgen voor directer contact tussen kiezers en gekozenen, wat zou leiden tot betere vertegenwoordiging, hogere politieke participatie en grotere politieke legitimiteit.

Hoewel dit soort theorieën nog steeds weerklank vindt in de vergelijkende politieke wetenschap (zie Anckar, 2010; Somin, 2013), blijkt uit de politieke praktijk in kleine (eiland)staten dat kleinschaligheid in sommige opzichten ook een obstakel kan vormen voor democratische ontwikkeling. De directe contacten tussen burgers en politici leiden tot overlappende professionele en privérelaties, wat zorgt voor belangenconflicten en particularistische politiek (Sutton, 2007; Veenendaal, 2014). Door de grotere homogeniteit is politiek in kleine samenlevingen meer gericht op persoonlijke dan inhoudelijke of ideologische verschillen, en deze personalistische politiek zorgt voor sterke polarisatie en een zwakkere politieke vertegenwoordiging (Richards, 1982; Veenendaal, 2013). Ten slotte hebben kleine samenlevingen vaak een zeer dominante en sterke uitvoerende macht, terwijl andere instituties - waaronder het parlement, de media of maatschappelijke organisaties - juist een zwakkere rol spelen. Gezamenlijk zorgen deze dynamieken voor een informele politieke praktijk die een stuk minder democratisch functioneert dan de formele politieke structuren doen vermoeden (Baldacchino, 2012; Erk \& Veenendaal, 2014).

Hoewel politiek in veel nieuwe democratieën gekenmerkt wordt door een discrepantie tussen formele politieke instituties en de informele politieke praktijk (Lauth, 2000; Helmke \& Levitsky, 2004), geldt dit dus in het bijzonder voor kleine (eiland)maatschappijen. Deze samenlevingen hebben een grotere mate van intimiteit en sociale verwevenheid, en door de kleinschaligheid kunnen burgers en politici direct met elkaar communiceren (Dahl \& Tufte, 1973). Hierdoor is de kans groter dat politieke processen op een persoonlijk niveau en buiten de formele politieke kanalen plaatsvinden (Veenendaal, 2014; Corbett, 2015). Kleine (eiland)staten worden doorgaans echter buitengesloten van vergelijkend wetenschappelijk onderzoek, waardoor relatief weinig bekend is over hun politieke systemen (Corbett, 2015). De kennis die we over deze staten hebben, is voornamelijk gebaseerd op de formele aspecten van hun politieke systemen, terwijl dit juist in deze staten dus weinig lijkt te zeggen over hoe politiek in de praktijk werkt. Door 
de relatieve zwakte van formele instituties worden politieke ontwikkelingen in kleine eilandsamenlevingen sterk gestuurd door individuele politici en hun onderlinge verhouding. In de praktijk betekent dit dat individueel leiderschap en de relaties binnen de politieke elite een sterkere invloed hebben op het functioneren van het bestuur dan in grotere landen.

In de volgende paragrafen zullen de informele politieke dynamieken op Bonaire, Sint-Eustatius en Saba worden besproken en geanalyseerd. Uit het veldonderzoek is gebleken dat de informele politiek op deze eilanden sterk beïnvloed wordt door twee contextuele factoren, te weten de reeds hierboven besproken kleinschaligheid en de dieperliggende politieke dynamieken van de postkoloniale Cariben. Daarom zal ten eerste worden stilgestaan bij de invloed die deze twee factoren uitoefenen op de politiek van de drie eilanden. Vervolgens wordt bekeken hoe de uit Nederland afkomstige politieke instituties, en in het bijzonder het in 2010 ingevoerde Nederlandse gemeentemodel, zich verhouden tot de bestaande politieke cultuur. Op basis hiervan zal worden verklaard waarom de invoering van het nieuwe bestuursmodel tot dusverre nog niet heeft geleid tot een sterker bestuur op de eilanden.

\section{Kleinschaligheid: iedereen kent iedereen}

Met respectievelijk 18.000, 4000 en 2000 inwoners zijn Bonaire, Sint-Eustatius en Saba naar internationale maatstaven bijzonder klein te noemen. Qua bevolkingsgrootte zijn de eilanden vergelijkbaar of kleiner dan de kleinste soevereine staten ter wereld, en ook binnen de categorie van niet-soevereine territoria en overzeese gebiedsdelen behoren zij tot de kleinste eenheden (vergelijk Aldrich \& Connell, 1998; Baldacchino, 2010; Rezvani, 2014). ${ }^{3}$ De kleinschaligheid van de openbare lichamen wordt versterkt door hun eilandstatus, die historisch gezien heeft gezorgd voor geografisch isolement, waardoor de eilandsamenlevingen zich lange tijd zonder grote invloed van buitenaf konden ontwikkelen. Sint-Eustatius en Saba zijn als buureilanden beide onderdeel van de Bovenwindse Caribische eilanden, terwijl het 900 kilometer zuidelijker gelegen Bonaire behoort tot de Benedenwindse eilanden, die vlak voor de kust van Venezuela liggen. Hoewel de BES-eilanden alle drie klein zijn, is de bevolking van Bonaire toch negen keer zo groot als die van Saba, en zoals uit de analyse zal blijken heeft dit zeker ook consequenties voor het functioneren van de politiek.

Op alle drie de eilanden is politiek grotendeels een zaak van families. De toonaangevende politici op de eilanden komen voort uit de voornaamste families, en veel politici zijn ook (indirecte) familieleden van elkaar. Op de kleinste eilanden is de grootte van de familie een goede indicator voor de politieke steun die een kandidaat kan verwachten tijdens de verkiezingen, aangezien familiebanden een belangrijke factor vormen bij het stemgedrag (Ayisi, 1995, 68; Klomp, 1983, 167; Sullivan, 2006, 99). De invloed van families op de politiek werd bijvoorbeeld als volgt bevestigd door een politica op Saba: 
'I think you almost feel obligated to vote for your family, or they make you feel obligated. If you don't, they make you feel guilty. My family in particular always supported the WIPM party; from when I was a child we just supported the WIPM party. And your parents tell you "oh elections are coming up and we have to vote, and everybody has to vote for the WIPM party".'

De geringe omvang van het electoraat betekent dat de eilandpolitici vrijwel alle kiezers persoonlijk kennen, of in ieder geval weten tot welke familie bepaalde kiezers behoren. Dit leidt tot het verschijnsel van overlappende of doorkruisende rollen: een politicus heeft een vertegenwoordigende (professionele) relatie met zijn (of haar) kiezers, maar heeft daarnaast met veel kiezers ook een persoonlijke relatie, bijvoorbeeld als familielid, vriend(in), buurman of -vrouw, lid van dezelfde kerkgemeenschap, of lid van dezelfde sportclub (vergelijk Ott, 2000). Deze meerdere en overlappende relaties zorgen voor een sterke vermenging van privérelaties en politiek, wat resulteert in een politiek die vooral draait om persoonlijke relaties en vice versa. Op de drie eilanden is politiek in alle facetten van de samenleving sterk aanwezig, en worden persoonlijke relaties ook voor een belangrijk gedeelte door politieke verhoudingen beïnvloed.

In de politieke arena leidt het belang van persoonlijke relaties tot een gebrek aan inhoudelijke, ideologische of programmatische politiek. Politici worden veeleer gekozen op basis van persoonlijke relaties dan op basis van specifieke beleidsvoorstellen, en verkiezingsprogramma's zijn zeer beperkt en bevatten zelden concrete politieke plannen (Oostindie \& Sutton, 2006). Op elk van de drie eilanden hebben zich in de loop van de tijd wel politieke partijen ontwikkeld, maar deze hebben geen duidelijke ideologische signatuur, waardoor er grote inhoudelijke meningsverschillen bestaan tussen afzonderlijke politici van dezelfde partij. Eric Ayisi (1995) beschrijft het gebrek aan inhoudelijke politiek op Sint-Eustatius bijvoorbeeld als volgt:

'The political rhetoric is about personalities, not ideologies. (...) The politics on the island are characterized by "opportunism" but not by any well-defined program. It has no particular party ideology. The people on the island do not believe in "isms" and when they are asked about the various ideological persuasions, they play ignorance.' (p. 69)

Op een enkele uitzondering na beaamden alle geïnterviewde politici op de drie eilanden dat de politieke partijen qua inhoud niet of nauwelijks van elkaar te onderscheiden zijn, en dat samenwerking tussen partijen en politici ook meer op basis van persoonlijke relaties dan op basis van inhoudelijke of ideologische congruentie tot stand komt. De afwezigheid van ideologie als bindmiddel zorgt ervoor dat deze politieke samenwerking doorgaans onvoorspelbaar en instabiel is, omdat persoonlijke conflicten geregeld kunnen leiden tot politieke afsplitsingen of de val van coalities.

Verschillende wetenschappers hebben betoogd dat kleinschalige samenlevingen homogener en daarom in politiek opzicht harmonieuzer zijn (Anckar, 2002; Diamond \& Tsalik, 1999; Srebrnik, 2004). De politieke praktijk in kleine eilands- 
amenlevingen wereldwijd laat echter zien dat de afwezigheid van inhoudelijke meningsverschillen niet automatisch leidt tot een meer consensusgericht systeem (Richards, 1982, Veenendaal, 2013). Aangezien persoonlijke conflicten vaak veel directer en scherper zijn dan inhoudelijke conflicten, is politiek op kleine eilanden juist bijzonder antagonistisch en gepolariseerd van aard. Dit geldt ook voor Bonaire, Sint-Eustatius en Saba: op alle drie de eilanden worden harde persoonlijke aanvallen niet geschuwd en bestaan verkiezingscampagnes voornamelijk uit het zwartmaken van politieke tegenstanders. Doordat de eilandsamenlevingen zeer gepolitiseerd zijn, beperkt deze polarisatie zich niet tot de politieke arena zelf. Een politica op Sint-Eustatius beschrijft de maatschappelijke polarisatie die zij ervaart als volgt:

'Some people wouldn't speak to me because I am from the [party] and they are from another party. They wouldn't speak to me because, you know. It's so personal how they take politics here (...) Instead of speaking to you, they would curse you; those type of things.'

De combinatie van persoonsgerichte en gepolariseerde politiek versterkt de neiging tot politieke instabiliteit op de eilanden, want het komt niet zelden voor dat een vriendschappelijke politieke samenwerking ineens uitmondt in een scherp persoonlijk conflict, of dat voormalige aartsvijanden elkaar plotseling vinden in een coalitie.

Het nauwe contact en de overlappende sociale rollen tussen kiezers en gekozenen op de eilanden leiden ook tot belangenconflicten. De meeste politici combineren hun functie met een baan in het bedrijfsleven, de media of een belangengroep, waardoor belangenverstrengeling vrijwel permanent op de loer ligt. Daarnaast leidt de kleinschaligheid op alle drie de eilanden tot particularistische relaties tussen burgers en politici, wat tot uiting komt in cliëntelisme, patronage en nepotisme. En zoals een politicus op Bonaire aangaf, worden op dit eiland bij verkiezingen soms ook stemmen gekocht:

'Het punt is dat er gesjoemeld wordt. Het ergste is dat sommige mensen hun stem dusdanig laag waarderen en dusdanig weinig resultaat voelen (...) dat zij bereid zijn hun stem te verkopen. Het erge is ook nog dat er politici zijn die bereid zijn stemmen te kopen. Als politicus sturen mensen jou een facebook message - je moet maar op facebook kijken - en ze vragen je om 400 dollar voor hun stem.'

Wat particularisme betreft werkt de kleinschaligheid als een tweesnijdend zwaard: enerzijds weten politici dat een klein aantal stemmen de doorslag zal geven en worden zij daarom in de verleiding gebracht om deze kiezers door middel van gunsten te verleiden, en anderzijds zijn kiezers zich bewust van de grote waarde van hun stem, waardoor zij politici onder druk kunnen zetten om hen van gunsten te voorzien. Verschillende politici gaven daarnaast aan dat kiezers ook grote sociale druk op hen uitoefenen, en dat het niet uitdelen van gunsten ook kan leiden tot negatieve sociale consequenties voor henzelf of hun familieleden. 


\section{De Caribische politieke cultuur: politricks en democrazy ${ }^{4}$}

Een tweede contextuele factor die grote invloed heeft op het functioneren van de politiek in Caribisch Nederland is de Caribische politieke cultuur. Ondanks het feit dat de eilanden al sinds de zeventiende eeuw onderdeel van Nederland zijn, is de manier van politiek bedrijven compleet anders dan in Europees Nederland, en veel meer vergelijkbaar met die van omliggende Caribische eilanden (Mamadouh \& Nauta, 2002). Dit kan grotendeels verklaard worden vanuit de vergelijkbare politieke geschiedenis, die gekenmerkt is door kolonialisme, slavernij en dwangarbeid. Terwijl het bestuur van de eilanden al in de koloniale tijd werd ingericht op basis van Nederlandse instituties, was het overgrote deel van de bevolking van de Nederlandse Antillen tot in midden van de twintigste eeuw uitgesloten van het kiesrecht en andere vormen van politieke participatie (Schrils, 1990, 45-48; Verton, 1973, 14-15). Net als in de Britse Cariben had de eilandbevolking dus wel te maken met de politieke instituties van de kolonisator, maar ervaarde zij deze instituties voornamelijk op een onderdrukkende manier. Waar de ontwikkeling van de parlementaire instituties in Nederland gepaard ging met de geleidelijke ontwikkeling van een democratisch systeem, werden deze instituties in de Cariben juist ingezet om het grootste deel van de bevolking te onderdrukken en uit te buiten (Hinds, 2008; Ryan, 1999).

Hoewel de lange ervaring met de uit Nederland afkomstige politieke instituties wellicht ten grondslag ligt aan het voortbestaan van de formele democratische structuren op de Nederlandse Caribische eilanden, kan deze ervaring ook worden gezien als oorzaak van de minder democratische politieke cultuur die op de eilanden heerst. De koloniale maatschappij van de Nederlandse Antillen was sterk gestratificeerd en hiërarchisch van aard, en deze factoren kenmerken ook vandaag de dag de relatie tussen kiezers en politieke leiders. Dit uit zich ten eerste in een passieve en onderdanige houding ten opzichte van gezagsdragers. Donald Peters (1992) beschrijft dit aspect van het systeem in de oostelijke Cariben als volgt:

'Democracy means to the Caribbean people the freedom to elect their leaders, but immediately after the elections their political participation ceases. They withdraw from the political process completely and assume their status as subjects of the leaders.' (p. 133)

Net als op andere kleine Caribische eilanden is de vrijwel almachtige positie van politieke leiders een belangrijk kenmerk van het bestuur in Caribisch Nederland. Gezagsdragers worden nauwelijks door hun kiezers gecontroleerd, en ondervinden ook weinig weerstand vanuit bijvoorbeeld de media of de eigen politieke partij. In haar studie over Bonaire concludeerde Ank Klomp dan ook: '[b]ezien vanuit het ideaal van interne democratie is het dominerende leiderschap het voornaamste probleem' (1983, p. 147).

De dominante positie van politieke leiders wordt versterkt door het wijdverspreide cliëntelisme. In een context waarin sociale voorzieningen grotendeels afwezig zijn, vervult cliëntelisme net als in de Engelstalige Cariben een belangrijke 
rol bij de economische herverdeling, en voorziet daarmee voor de onderklasse in een sociaal vangnet (Duncan \& Woods, 2007, 211). Dit zorgt er echter ook voor dat veel kiezers economisch en sociaal afhankelijk zijn van bepaalde politici. Zoals een politica op Saba aangaf, is het natuurlijk voor politici om gunsten uit te delen aan de eigen achterban:

'Anybody will protect their own. If you have an investment, you are going to do whatever you can to protect it. So if you're in power, out of power, you're still going to protect your own, so I think it is a human instinct and that's what this is.'

Doordat politici de publieke middelen controleren waar veel kiezers van afhankelijk zijn, kunnen zij niet alleen in de politiek maar ook in de maatschappij als geheel een zeer dominante rol spelen. Anderzijds worden politici door hun kiezers ook geregeld onder druk gezet om gunsten uit de delen. Zoals een politica op SintEustatius beschreef, kunnen burgers wat dit betreft behoorlijk assertief zijn bij het benaderen van hun politieke vertegenwoordigers:

'Everybody is feeling whatever they are feeling, and they want you to know. They want a job and they say, "I voted for you so you have to give me a job" and those kinds of things.'

De cliëntelistische relatie tussen kiezers en gekozenen is een cruciaal aspect van het Caribische democratische systeem, en volgens sommige auteurs vormt cliëntelisme zelfs het fundament van de democratische ontwikkeling in de regio (Edie 1994, 212; Duncan \& Woods, 2007; Hinds, 2008). De politieke praktijk in Caribisch Nederland en andere Caribische eilanden laat echter ook zien dat cliëntelisme zorgt voor belangenverstrengeling en het misbruik van publieke gelden, waardoor het inefficiënt en slecht bestuur in de hand werkt. Een bestuurder op Sint-Eustatius gaf aan dat dit ook op zijn eiland een oorzaak is van zwak bestuur:

'When people get in politics and they get into government, they misuse the funds: it's just family and friends. And if they view you as a special friend, you get favors. That's what happens in our small communities.'

In combinatie met de sterke politieke polarisatie zorgen de sterke machtspositie van politici en het cliëntelisme er ook voor dat (de aanhangers van) politieke tegenstanders soms geïntimideerd of bedreigd worden; een fenomeen dat in de Engelstalige Cariben victimization wordt genoemd. Door de kleinschaligheid en het daarmee gepaard gaande gebrek aan politieke anonimiteit weten politici goed welke kiezers zij tot hun aanhangers of tot hun tegenstanders kunnen rekenen, en het bevoordelen van supporters gaat vanzelfsprekend gepaard met het benadelen van de aanhang van de tegenpartij. Dit kan zich uiten in het ontslag van ambtenaren of het onthouden van bepaalde publieke diensten aan burgers, maar ook in intimidatie en bedreigingen. Uit interviews bleek dat victimization vooral op 
Bonaire soms voorkomt, zoals bijvoorbeeld werd aangegeven door een geïnterviewde politica:

'Ja, het is heel erg. Het is eigenlijk triest, heel triest. Je wordt persoonlijk afgerekend. Men erkent de scheiding niet tussen politiek en de persoonlijke leven. Het is ontiegelijk moeilijk. En men wil gewoon persisteren met het oude systeem van politiek van vroeger. Je hele familie, iedereen wordt afgerekend.'

Juist omdat zo veel kiezers afhankelijk zijn van de politiek, hebben politici de middelen in handen om individuele burgers onder druk te zetten. Dit draagt vervolgens bij aan de instandhouding van de angstcultuur, die vaak wordt gezien als kenmerk van de Antilliaanse samenleving (Marcha \& Verweel, 2003). Een vooraanstaand bestuurder op Bonaire gaf aan dat er onder ambtenaren inderdaad een dergelijke angstcultuur bestaat:

'Het is hier nog steeds heel erg regeren vanuit de macht en ambtenaren ook bedreigen, dat gebeurt ook heel vaak. Het is gewoon aan de orde van de dag dat ambtenaren bedreigd worden of dat ze zich bedreigd voelen.'

Een laatste onderscheidend element van de Caribische politiek is de rol van retoriek en persoonlijke aanvallen op politieke tegenstanders. De geschiedenis van kolonisatie en slavernij speelt nog steeds een vooraanstaande rol in het politieke discours op de eilanden, en er worden in het politieke debat voortdurend verwijzingen gemaakt naar onderdrukking, racisme, de vrijheidsstrijd en de emancipatie. Hoewel de politieke partijen ideologisch gezien nauwelijks van elkaar verschillen, worden de persoonlijke verschillen vaak breed uitvergroot, en worden aanvallen ad hominem niet geschuwd. Politiek theater en kleurrijke retoriek vormen een essentieel onderdeel van de Caribische politiek, maar leiden ook af van de inhoud, zoals een politicus op Sint-Eustatius aangaf tijdens een interview:

'Politicians have become accustomed to what the public is looking for. There are a lot in the public who like that kind of political theater. And they would say "oh you handled them well today!". So, they like that, but I think in going forward we need to try as much as possible to move away from that and really stick to the issues at hand.'

Tijdens publieke debatten in de eilandsraden van de drie Caribische gemeenten wordt inderdaad veel tijd besteed aan procedurele kwesties en aanvallen op politieke tegenstanders, waardoor er weinig tijd overblijft om over inhoudelijke onderwerpen van gedachten te wisselen. Plannen en voorstellen van de bestuurscoalitie worden vrijwel automatisch afgekraakt door de oppositie, en andersom zijn coalitiepartijen ook geneigd om de inbreng van de oppositie meteen af te wijzen. Deze relatie tussen coalitie en oppositie werd door een politicus op Sint-Eustatius als volgt beschreven: 
'Of course, the opposition has a role, and their role, as much as possible, is to create the impression that the government is incompetent and doesn't know what they are doing; that the policies, plans and ideas are not good. If you see Facebook and read some of their attacks, some people are even calling for my head.'

Door de kleinschaligheid kennen politici elkaar meestal ook in de persoonlijke sfeer, waardoor politieke conflicten ook een persoonlijke dimensie hebben. In sommige gevallen worden scheldwoorden gebruikt om politieke tegenstanders aan te duiden: zo wordt de leider van de oppositiepartij op Sint-Eustatius, de heer Sneek, in toespraken van de leider van de grootste regeringspartij (Clyde van Putten) bijvoorbeeld herhaaldelijk the snake (de slang) genoemd.

\section{Waarom het Nederlandse gemeentemodel niet leidt tot beter bestuur}

Hoewel de politieke instituties van Bonaire, Saba en Sint-Eustatius sinds 2010 vrijwel gelijk zijn aan die van Nederlandse gemeenten, blijkt uit de voorgaande twee paragrafen dat de kleinschaligheid en politieke cultuur van de eilanden zorgen voor een aantal bijzondere informele politieke dynamieken. Deze informele patronen zorgen ervoor dat de uit Nederland afkomstige instituties, waaronder het in 2010 geïntroduceerde bestuursmodel, ${ }^{5}$ in Caribisch Nederland anders functioneren dan zij in de Europese Nederlandse context doen. Een belangrijk kenmerk van het Nederlandse systeem is het proportionele kiesstelsel, dat ook al vóór 2010 op de eilanden van kracht was. Net als in Europees Nederland resulteert dit kiesstelsel in een meerpartijensysteem en bestuurscoalities die bestaan uit meerdere partijen. Omdat in tegenstelling tot Nederland politieke partijen in Caribisch Nederland echter geen duidelijke ideologische grondslag hebben, komen bestuurscoalities voornamelijk op basis van persoonlijke verhoudingen tot stand. Het gebrek aan ideologische of programmatische verbondenheid zorgt ervoor dat deze coalities zeer instabiel zijn, en dat het geregeld voorkomt dat individuele politici of partijen zich terugtrekken uit een politieke samenwerking. Het zeer kleine aantal zetels in de eilandsraad (vijf in het geval van Saba en Sint-Eustatius, en negen in het geval van Bonaire) leidt daarnaast tot een sterke politieke macht van individuele raadsleden, die plotsklaps kunnen besluiten hun steun aan de regeringscoalitie in te trekken en in plaats daarvan de oppositie in het zadel te helpen. Dergelijke situaties hebben zich sinds 2010 zeer frequent voorgedaan op Bonaire en Sint-Eustatius. Een Bonairiaanse politicus uitte daar tijdens een interview zijn frustraties over:

'Ja, dat is ook zoiets, raadsleden breken zomaar af van de coalitie. Dat is heel frappant, twee raadsleden breken af zonder een coalitievergadering vooraf te hebben. Dus je hebt geen coalitievergadering gehad waarin je zegt: "ik ben ik het daarmee niet eens". En dan gaan we het debat in en je krijgt daar gewoon te horen van: "ik steun het niet meer".' 
Tabel $1 \quad$ Politieke instabiliteit in Caribisch Nederland tussen 2010 en 2017

\begin{tabular}{llll}
\hline & Bonaire & Sint-Eustatius & Saba \\
\hline Totaal aantal bestuurswisselingen $^{6}$ & 9 & II & I \\
Wisselingen door verkiezingen & 2 & 2 & 0 \\
Tussentijdse wisselingen & 7 & 9 & I \\
\hline
\end{tabular}

In tabel 1 is een overzicht gegeven van het aantal bestuurswisselingen op de drie eilanden in de periode van 2010 tot nu. Hieruit blijkt duidelijk dat bestuurlijke instabiliteit op Bonaire en Sint-Eustatius een groot probleem vormt, terwijl het bestuur van Saba juist heel stabiel is.

Politieke instabiliteit als gevolg van het evenredige kiesstelsel en de kleinschaligheid speelde ook vóór 2010 een grote rol op de eilanden, maar is door de invoering van het nieuwe bestuursmodel verder versterkt. Het nieuwe bestuursmodel wordt namelijk gekenmerkt door dualisme tussen de raad en het bestuurscollege (bestaande uit een benoemde gezaghebber en indirect gekozen gedeputeerden), waardoor raadsleden niet tegelijkertijd meer gedeputeerden (wethouders) kunnen zijn. In de praktijk betekent dit dat partijleiders, die meestal zitting nemen in het bestuurscollege, nu afhankelijk zijn van de steun van andere partijleden in de eilandsraad. Zowel op Bonaire als op Sint-Eustatius is het meermaals voorgekomen dat deze partijleden plotsklaps hun steun introkken, waardoor partijleiders politiek gezien volledig uitgeschakeld werden (Nauta, 2015). Een politica op SintEustatius, waar sinds 2010 maar liefst zes keer van bestuurscollege gewisseld werd, geeft aan dat het dualisme aldus inderdaad heeft geleid tot een versterking van de instabiliteit:

'I think the split in all these different parties came about since we have the new system of dualism; it came from that. Because everyone is a product of some other party that had been there before. And some were disgruntled that things did not going according to plan, so they split and went somewhere else and formed their own party.'

De aanhoudende instabiliteit op Bonaire en Sint-Eustatius is een belangrijke verklaring voor het zwakke bestuur op deze eilanden, en verklaart ook waarom Saba, dat sinds 2010 steeds door dezelfde politieke partij bestuurd is, succesvoller is geweest in het realiseren van langetermijnbeleid. Het is geen toeval dat juist het zeer instabiele Sint-Eustatius in de zomer van 2015 onder hoger toezicht van het Rijk werd gesteld vanwege de problematische financiële en bestuurlijke situatie op dit eiland. Een vooraanstaand bestuurder op het eiland gaf aan niet verbaasd te zijn over de maatregel:

'I certainly wasn't surprised, and I think many persons in our community were certainly not surprised. And I think it is perhaps a necessary step that 
allows us to focus on the things that are necessary to strengthen our governmental structure to be able to execute the tasks and responsibilities that we aspire to have.'

Naast de instabiliteit zorgt ook het cliëntelisme voor een financieel beleid dat op korte termijn misschien electorale voordelen oplevert, maar op langere termijn niet rendabel is. Uit interviews op de drie eilanden bleek dat vooral het stemmen bij volmacht wordt gezien als een belangrijke stimulans voor cliëntelisme. Volmachten werden in 2010 op de eilanden van Caribisch Nederland geherintroduceerd, maar net als in het verleden is op alle drie de eilanden gebleken dat er geregeld volmachten geronseld worden en dat sommige kiezers in ruil voor geld een volmacht weggeven: .

'Het probleem is dat er blijkbaar voldoende ruimte is om te sjoemelen met de volmachten. En dan moet je altijd gaan kijken: ga ik het middel weghalen waarvan mensen misbruik maken?'

Naast het stemmen bij volmacht werd door sommige respondenten ook de mogelijkheid tot het uitbrengen van een persoonlijke voorkeursstem gezien als een regel die cliëntelisme in de hand werkt: politici kunnen hierdoor vrij nauwkeurig reconstrueren welke kiezers voor hen gestemd hebben, terwijl dit bij een stem op de partij als geheel minder goed te traceren zou zijn. Ten slotte werd de in Nederland opgelaaide discussie over de zogenaamde 'stemfie' - foto's die kiezers van zichzelf en hun stembiljet nemen in het stemhokje - in Caribisch Nederland met argusogen gevolgd. In kleine eilandsamenlevingen biedt dit politici een uitgelezen kans om te controleren of kiezers hun deel van de cliëntelistische uitruil daadwerkelijk nakomen.

Hoewel het in 2010 ingevoerde dualisme als doel had om de democratische controle van de eilandsraad op het bestuurscollege te vergroten, blijkt uit interviews dat dit onderdeel van het bestuursmodel niet goed van de grond komt. Het autoritaire leiderschap, de afwezigheid van ideologie, en de sterke polarisatie zorgen er in de praktijk voor dat de eilandsraden van Caribisch Nederland een zwakke positie hebben ten opzichte van het bestuurscollege, en maar zelden effectieve controle op het bestuur uitoefenen. Politieke partijen worden in de regel gedomineerd door individuele leiders en er is weinig ruimte voor afwijkende meningen, waardoor conflicten binnen partijen doorgaans snel resulteren in een breuk of afsplitsing. Loyale raadsleden van coalitiepartijen zullen daarentegen zelden commentaar of kritiek leveren op de eigen bestuurders en politieke leiders, en commentaar dat wordt aangedragen door de oppositie wordt doorgaans vrijwel meteen van tafel geveegd. Deze dynamiek werd als volgt bevestigd door een lid van de eilandsraad op Sint-Eustatius:

'There is no real separation between the commissioners and the members of the island council. So if we as opposition tell the commissioners "you shouldn't do this and you shouldn't do that", the three members from the 
coalition will always agree with the commissioners. So right now, it's not really working the way it is supposed to work.'

Saba heeft van de drie eilanden verreweg de meeste politieke stabiliteit, maar op dit eiland zorgt de bestuurlijke dominantie van de regeringspartij (de WIPM ${ }^{8}$ ) ervoor dat de eilandsraad een ondergeschikte rol speelt, en volgens veel respondenten vinden er op dit eiland te weinig bijeenkomsten van de eilandsraad plaats. De zwakke rol van de eilandsraad ten opzichte van de uitvoerende macht draagt hier ook bij aan de afwezigheid van een publiek debat over beleidsinhoudelijke vraagstukken. Omdat debatten in de eilandsraad voornamelijk gaan over persoonlijke ruzies en politieke intriges, wordt in de praktijk de macht van het bestuurscollege versterkt. Eilandbestuurders leggen zelden verantwoording af voor het gevoerde beleid, noch in de eilandsraad, noch in de media. Hierdoor is de kans dat er bestuurlijke fouten worden gemaakt groter, en is het bovendien onwaarschijnlijk dat slecht functionerende bestuurders worden terechtgewezen of vervangen. Een hoge ambtenaar op Bonaire beschreef deze dynamiek als volgt:

'Nee, het gaat bijna niet om de inhoud. De eilandsraad heeft bijvoorbeeld nog nooit - in ieder geval voor zo ver ik kan traceren - een kaderstellend programma gemaakt. Een paar bestuurscolleges hadden een programma, maar een paar ook niet. Dus je wordt geregeerd door meer emotionele dingen, en zo nu en dan probeert men zakelijk te zijn, maar dan wordt die zakelijkheid weer ingeperkt door de waan van de dag.'

De in deze paragraaf verrichte analyse laat zien dat de informele politieke dynamieken in Caribisch Nederland een sterk effect hebben op het functioneren van het uit Nederland afkomstige bestuursmodel. Het gemeentemodel dat in 2010 is geïntroduceerd is in dit opzicht vooralsnog geen verbetering, en lijkt mogelijk zelfs een verslechtering van de situatie van voor 2010 te betekenen.

\section{Verschillen tussen de eilanden}

In de voorgaande paragrafen is een aantal gemeenschappelijke informele politieke dynamieken van Bonaire, Sint-Eustatius en Saba beschreven, die grotendeels worden ingegeven door de kleinschaligheid en de Caribische politieke cultuur. Er bestaan tussen de drie eilanden echter ook enkele belangrijke verschillen, die voornamelijk voortvloeien uit divergerende historische en demografische ontwikkelingen, maar ook verklaard kunnen worden vanuit verschillen in politiek leiderschap en verhoudingen binnen politieke elites. In deze paragraaf zal ik op basis van deze factoren verklaren waarom Saba bestuurlijk het beste functioneert, terwijl Sint-Eustatius van de drie eilanden het zwakste bestuur heeft.

Binnen de Nederlandse Antillen hadden Bonaire, Sint-Eustatius en Saba allen een ondergeschikte positie ten opzichte van Curaçao, maar bestonden er ook al enkele belangrijke verschillen tussen deze eilanden, die na 2010 verder lijken te zijn uitgekristalliseerd. Als kleiner buureiland van Curaçao vertoont Bonaire met dit 
eiland een aantal belangrijke gelijkenissen, terwijl Saba en Sint-Eustatius qua cultuur meer lijken op de omringende Oost-Caribische eilanden, en in het bijzonder Sint-Maarten. Toch zijn juist tussen Saba en Sint-Eustatius, eilanden die amper 30 kilometer van elkaar verwijderd zijn, in bestuurlijk en politiek opzicht de grootste verschillen te zien. Zoals uit deze paragraaf zal blijken, kan dit vooral verklaard worden door uiteenlopende historische, demografische en culturele ontwikkelingen, maar ook vanuit verschillen tussen de individuele politici die deze eilanden bestuurd hebben.

Met slechts 2000 inwoners is Saba van de drie eilanden het kleinste, en de Sabaanse bevolking is verspreid over vier dorpen. Saba is zeer bergachtig, en het ontoegankelijke terrein zorgt voor veel infrastructurele hindernissen, waardoor de transportmogelijkheden tussen de dorpen lang zeer gebrekkig waren. Om in deze omgeving te kunnen overleven waren Sabanen lang op hun eigen vindingrijkheid en doorzettingsvermogen aangewezen, en in de jaren veertig van de vorige eeuw hebben zij met eigen handen hun befaamde weg (the Road) gebouwd, die ook nu nog symbool staat voor de Sabaanse vastberadenheid. Mede door de natuurlijke belemmeringen heeft het eiland nooit een grootschalige plantageeconomie gehad, al waren er wel slaven op het eiland aanwezig (Sullivan, 2006). Tot het midden van de twintigste eeuw was de meerderheid van de Sabaanse bevolking echter van Europese origine, en deze witte Sabanen stammen af van Britse, Ierse, Schotse en Nederlandse zeevaarders en piraten. De aanwezigheid van een significante groep bewoners van Europese herkomst maakt Saba uniek in de oostelijke Cariben, en hoewel er door de kleinschaligheid relatief veel contact was tussen Afro-Sabanen en Sabanen met een Europese afkomst, zijn er nog steeds nauwelijks gemengde huwelijken (Sullivan, 2006, 97-98).

Van de drie eilanden in Caribisch Nederland functioneert Saba in bestuurlijk opzicht het beste, en het is bijvoorbeeld het enige eiland dat al enkele jaren een sluitende begroting en door Den Haag goedgekeurde jaarrekening heeft. Geïnterviewde politici op Saba, maar ook op de andere eilanden, verwijzen bij het verklaren van deze uitzonderingspositie naar de hiervoor genoemde kenmerken van Saba, en geven aan dat Sabanen gewend zijn de handen uit de mouwen te steken en zelf het initiatief te nemen. Een Sabaanse politica gaf bijvoorbeeld aan:

'I think, just knowing the culture of us: yeah, we had slavery, we have experienced a lot of hardships, but we are resilient. We didn't lose hope and said: "okay, that's it" and stayed that way. We don't always live in the past, we try to move on. We always ask: 'What are we going to do? How are we going to advance ourselves?' We are very futuristic in a certain sense.'

Een belangrijk verschil met de andere eilanden is bovendien dat Saba een tweepartijensysteem heeft, waarbij één partij (de Windward Islands People's Movement - WIPM) al lange tijd alleen het bestuur vormt en doorgaans zeer competente bestuurders geleverd heeft. Politieke afsplitsingen komen op Saba nauwelijks voor, waardoor het eiland veel meer bestuurlijke continuïteit heeft dan de andere eilanden. Bovendien is de WIPM - die in 1970 is opgericht door eilandhistoricus Will Johnson - zeker binnen de Caribische context een bijzonder goed 
georganiseerde politieke partij, en ook volgens politici van de oppositionele Saba Labour Party draagt dit bij aan de bestuurlijke kwaliteit van het eiland:

'I think the WIPM party has been there for a very long time; they are very structured, organized, modern. You know, they have the whole party program, they have the support system. Mr. Johnson, he knows a lot of people, he is in contact with a lot of people, and he built that strong background, and that is so important.'

Net als op de andere eilanden spelen persoonlijke ruzies en cliëntelisme op Saba een grote rol. Toch lijkt de verdeeldheid op dit eiland minder scherp te zijn dan op de andere eilanden, en blijft de relatie tussen de twee partijen behoorlijk vriendelijk. Dit heeft voor een groot deel te maken met de aimabelere relaties tussen individuele politici op Saba, en met de sterke politieke rol die Will Johnson en zijn partij in de laatste decennia op het eiland hebben gespeeld.

De situatie op Sint-Eustatius is geheel anders. Dit eiland kent een glorieuze geschiedenis als de Golden Rock, en was in de achttiende eeuw een van de belangrijkste doorvoerhavens van goederen en slaven in het Caribisch gebied (Ayisi, 1995; Roitman \& Jordaan, 2015; Van den Bor, 1979). Sinds die glorietijd is het eiland in verval geraakt, en binnen de Nederlandse Antillen was het volgens commentatoren het meest armlastige en hulpbehoevende gebied. In tegenstelling tot Saba had Sint-Eustatius een aantal grote plantages, en de geschiedenis van slavernij en onderdrukking speelt een grote rol in het politieke discours op het eiland. Dit vertaalt zich bijvoorbeeld in zeer scherpe retoriek tegen politieke opponenten en Nederland, die ook zorgt voor spanningen op het eiland:

"There was a recent broadcast by the government leader on the local TV, and he is talking about "my country", "my nation", and he's talking about the color of people's faces. That kind of conversation polarizes people's opinions on this island. He was reported six days ago in the Dutch press talking about how there would be rivers of blood on the island.'

In vergelijking met de andere eilanden speelt ook religie op Sint-Eustatius een zeer grote rol, die doorwerkt in de politiek. Het eiland is religieus zeer verdeeld, en heeft een grote adventistengemeenschap die weinig tolerant is tegenover andere religies (Van den Bor, 1979, 213-214). Dit zorgt niet alleen voor maatschappelijke spanningen, maar ook voor politieke verdeeldheid, zoals een Statiaanse politicus aangeeft:

'And so in the politics here, we have many groups. We have a lot of different religious organizations, different than in Saba, where you have a few. Here we have maybe 10, 15 different religions. And they play a role in the political process. Not openly, but you will find more people from certain religions in certain political parties, for example.' 
Mede door de religieuze verdeeldheid heeft Sint-Eustatius altijd een groter aantal politieke partijen gehad, maar sinds 2010 is de politieke fragmentatie sterk toegenomen. Bovendien zijn de relaties tussen de Statiaanse politici veel vijandelijker dan op de andere twee eilanden (Veenendaal, 2016). Een Nederlandse ambtenaar die op alle drie de eilanden heeft gewerkt, zegt hierover:

'St. Eustatius is een heel ander eiland met een heel andere mentaliteit, daar hakken mensen echt op elkaar in. Dat is een heel andere mentaliteit. Politiek heeft daar helemaal niks meer te maken met waar je echt voor staat; het gaat daar gewoon over vetes tussen families.'

Van de drie eilanden heeft Sint-Eustatius onmiskenbaar het zwakste bestuur, en sinds de zomer van 2015 staat het eiland onder bestuurlijk toezicht van de Nederlandse regering. Gevraagd naar de oorzaken hiervan wijzen respondenten vooral naar de politieke verdeeldheid en vijandelijkheid. Zo stelt een geïnterviewde journalist:

'In such a small island there is such division. Six political parties and we have a population of about 4.000 people, and we have approximately 2.000-something people eligible to vote. Six parties are too much. That also has a lot to do with persons being more personal about situations instead of taking the bigger picture for Statia.'

Ook is de bevolking van dit eiland volgens geïnterviewden passiever ten opzichte van haar bestuurders dan de inwoners van andere eilanden, en heerst er een sterkere welvaartsmentaliteit, waardoor cliëntelisme hier ook een grotere rol zou spelen. De Nederlandse regering concludeerde in 2015 dat er op het eiland 'herhaaldelijk aanstellingen worden gedaan waar geen basis voor is in de begroting', waardoor het eiland 'omvangrijke tekorten heeft opgelopen' (Rijksoverheid, 2015).

Bonaire is veruit het grootste van de drie eilanden, en als gevolg van migratie is het inwonertal van dit eiland de afgelopen jaren sterk gegroeid. Bonaire is altijd sterk gericht geweest op het grotere buureiland Curaçao, en was binnen de Nederlandse Antillen 'ook in economisch opzicht (...) met handen en voeten aan Curaçao gebonden' (Klomp, 1983, 41). In vergelijking met Curaçao was Bonaire een in economisch opzicht minder ontwikkeld en veel dunner bevolkt eiland, maar door exploitatie van de zoutpannen door slaven heeft Bonaire ook een grotendeels Afro-Caribische bevolking, die net als op Curaçao overwegend katholiek is. Vanaf het begin is de politieke ontwikkeling op Bonaire in handen geweest van zakenlieden, en er is altijd een sterke verwevenheid geweest tussen economische en politieke elites van het eiland (Klomp, 1983). Bonaire is qua bevolkingsaantal significant groter dan Saba en Sint-Eustatius, en een van de meest tastbare consequenties hiervan is dat geld een beduidend grotere rol speelt in de politiek. Zoals een vooraanstaande Bonairiaanse ambtenaar aangaf tijdens een interview: 
'Politieke keuzes hier worden gemaakt op basis van welke politieke familie aan de macht is. Dus de familie, de grote, politieke families bepalen samen met het bedrijfsleven wat er op het eiland gebeurt.'

Op de twee Bovenwindse eilanden is door de kleinschaligheid van een bedrijfsleven niet echt sprake, maar op Bonaire spelen zakenlieden volgens vrijwel alle respondenten wel een grote rol in de politiek. Geld is vanouds een belangrijk onderdeel van de 'machinepolitiek' (Klomp, 1983) op het eiland, en volgens respondenten worden bij verkiezingen niet zelden stemmen gekocht. Ook zijn er regelmatig aanwijzingen en beschuldigingen van corruptie en vastgoedfraude op Bonaire, terwijl dit soort zaken zich op de kleinste eilanden niet voor lijkt te doen (Verlaan, 2009).

Een ander mogelijk effect van de invloed van het bedrijfsleven op de Bonairiaanse politiek is dat de persoon van partijleider hier nog belangrijker lijkt te zijn dan op de andere twee eilanden, aangezien leiders behoren tot zowel de economische als de politieke elite. Net als op Saba en Sint-Eustatius draait de Bonairiaanse politiek vooral om persoonlijke relaties, maar meer dan op de twee kleinere eilanden is de partijleider de spil waarom alles draait, en de big man die aan de top van het patronagenetwerk staat. Ondanks het feit dat de partijleiders elkaar goed kennen en niet zelden familie van elkaar zijn, is de relatie tussen partijleiders doorgaans vijandelijk van aard en worden er vaak trucs uitgehaald om tegenstanders zwart te maken of te beschadigen (Klomp, 1983, 165-167). De hiervoor genoemde victimization speelt op Bonaire dan ook een grotere rol dan op Saba en Sint-Eustatius. Een Bonairiaans raadslid zei hierover tijdens een interview:

'De (...) partij heeft altijd geprobeerd om op de man te spelen. Ik weet dat ze vroeger mensen ervan hebben beticht dat ze homo waren en dan gingen ze naar Curaçao en daar werden ze opgesloten, een manier om je politieke rivaal om zeep te helpen. Vervolgens hebben ze altijd geprobeerd de (...) mensen de bak in te gooien.'

Door de kleinschaligheid en grote sociale verbondenheid beïnvloeden de rivaliteit en machtsstrijd tussen partijleiders niet alleen henzelf, maar hebben deze ook directe repercussies voor de personen in de omgeving van politici. Vrijwel alle geïnterviewde Bonairiaanse bestuurders gaven aan dat dit hun werk soms erg lastig maakt. Zoals een lid van het bestuurscollege aangaf:

'We hebben hier ook te maken met het feit dat die politieke rivaliteit je familie, kennissen en vrienden ook snel en negatief raakt. (...) Het feit dat jij politicus bent wordt gewoon doorgetrokken alsof je hele familie politicus is. Als jij nee hebt gestemd op iets waar anderen buiten graag een ja op hadden willen horen, dan krijgt je hele familie dat te horen en te voelen.'

Uit deze paragraaf is gebleken dat er naast alle overeenkomsten ook enkele belangrijke verschillen bestaan tussen de drie eilanden van Caribisch Nederland. Deze verschillen vertalen zich in de kwaliteit van het bestuur; terwijl Saba door 
zowel de Nederlandse regering als de interviewrespondenten geprezen wordt om de integriteit, stabiliteit en slagvaardigheid van het bestuur, wordt Sint-Eustatius wat dit betreft vrijwel alom als het meest problematische eiland beschouwd. Zoals eerder in dit artikel besproken werd, zorgt de zwakte van formele instituties ervoor dat individueel leiderschap van doorslaggevende invloed is op politieke ontwikkelingen in kleine eilandsamenlevingen. Uit de hierboven verrichte analyse blijkt dat de relaties binnen de Sabaanse politieke elite veel harmonieuzer zijn dan op Bonaire en Sint-Eustatius, en dat dit een belangrijke verklaring vormt voor verschillen in het bestuur van deze eilanden.

\section{Conclusie: implicaties voor het bredere debat over goed bestuur}

Net als Britse en Franse non-soevereine eilanden in het Caribisch gebied, hebben de Nederlandse Cariben vrijwel zonder aanpassingen de Nederlandse instituties overgenomen. De Britse, Franse en Nederlandse bestuursmodellen zijn echter alle door middel van een langdurig en idiosyncratisch proces ontstaan, en passen daarom niet automatisch goed in de context van kleinschalige Caribische eilanden. Zoals uit dit artikel gebleken is, heeft het Nederlandse model, dat gekenmerkt wordt door (extreem) proportionele verkiezingen, een meerpartijensysteem en coalitieregeringen, geheel andere politieke effecten in een informele context die beheerst wordt door personalistische politiek, cliëntelisme en patronage, en scherpe polarisatie. Net als Bonaire en Sint-Eustatius worden ook Curaçao en Sint-Maarten - twee eilanden die in 2010 autonome landen binnen het Koninkrijk geworden zijn - geplaagd door politieke fragmentatie en instabiliteit, en beide eilanden hebben sinds 2010 een gemiddelde van één regering per jaar gehad. In Caribisch Nederland lijkt de invoering van het Nederlandse gemeentemodel en het bijbehorende dualisme vooralsnog in ieder geval geen verbetering ten opzichte van de situatie van vóór 2010 te betekenen.

Binnen de Nederlandse regering bestond in 2010 onmiskenbaar de hoop dat de staatskundige integratie van Bonaire, Saba en Sint-Eustatius zou leiden tot een sterker openbaar bestuur. Deze hoop is vooralsnog zeker niet uitgekomen, en het is de vraag of dit in de toekomst wel zal gaan gebeuren. Aangezien zowel de kleinschaligheid als de Caribische politieke cultuur niet zomaar veranderd kan worden, is het de vraag of goed bestuur überhaupt van de grond kan komen op de eilanden. Ank Klomp zegt over het cliëntelisme bijvoorbeeld dat ' $[\mathrm{m}]$ isschien moet worden geconstateerd dat particularisme onlosmakelijk verbonden is met kleinschaligheid en daarom (...) in zo'n gemeenschap niet zal verdwijnen' (1983, p. 215). Uit de literatuur over zowel soevereine kleine eilandstaten als non-soevereine Amerikaanse, Britse en Franse gebieden in de regio blijkt dat de Nederlandse Caribische eilanden geen uitzonderingspositie bekleden, en dat soortgelijke bestuurlijke problemen zich ook in naburige eilanden voordoen (Peters, 1992; Hinds, 2008; Clegg, 2009). Het feit dat deze eilanden een ander bestuursmodel hebben, laat zien dat formele structuren geen groot effect hebben op de kwaliteit van het openbaar bestuur, dat veel meer beïnvloed lijkt te worden door de prevalerende informele politiek. 
Zoals in het theoretische gedeelte van dit artikel besproken is, zorgt de combinatie van zwakke formele instituties en sterke informele politiek ervoor dat individueel leiderschap en de relaties binnen de politieke elite van grote invloed zijn op het functioneren van de politiek en het bestuur. Uit de vergelijking tussen de drie eilanden bleek dan ook dat de uitzonderingspositie van Saba grotendeels te verklaren is vanuit de hogere kwaliteit van individueel leiderschap en de meer gemoedelijke relaties tussen individuele politici op dit eiland. Dit suggereert dat pogingen om de bestuurskwaliteit in Caribisch Nederland te verbeteren wellicht niet gevonden moeten worden in institutionele oplossingen, maar zich veel meer zouden moeten richten op het opleiden en trainen van bestuurders en politici op de eilanden.

\section{Dankwoord}

Graag zou ik de twee anonieme referenten willen bedanken voor hun constructieve en nuttige commentaar. Verder zou ik Gert Oostindie willen bedanken voor zijn commentaar op een eerdere versie van dit artikel.

\section{Bijlage: geanonimiseerde lijst met afgenomen interviews}

\section{Sint-Eustatius:}

\begin{tabular}{ll}
\hline 17 juni 2015 & Journalist voor een krant. \\
18 juni 2015 & Voormalig eilandsraadslid (20II-20I5). \\
18 juni 2015 & Eilandsraadslid voor de Progressive Labour Party. \\
19 juni 2015 & Voormalig eilandsraadslid (20II-20I5). \\
19 juni 2015 & Eilandsraadslid voor de Democratic Party. \\
20 juni 2015 & Leden van een non-governmental organization die zich bezighoudt \\
& met politiek op Sint-Eustatius. \\
22 juni 2015 & Nederlandse ambtenaar werkzaam bij de Rijksdienst Caribisch \\
22 juni 2015 & Nederland (RCN). \\
22 juni 2015 & Hoge publieke functionaris op Sint-Eustatius. \\
22 juni 2015 & Oud-gedeputeerde in het bestuurscollege. \\
23 juni 2015 & Voormalig eilandsraadslid (20II-20I5). \\
24 juni 2015 & Journalist voor een radio- en televisiestation. \\
24 juni 2015 & Gedeputeerde in het bestuurscollege. \\
25 juni 2015 & Eilandsraadslid voor de Progressive Labour Party. \\
26 juni 2015 & Eilandsraadslid voor de United People's Coalition. \\
28 juni 2015 & Eilandsraadslid voor de Democratic Party. \\
\hline
\end{tabular}


Saba:

\begin{tabular}{ll}
\hline II januari 2016 & $\begin{array}{l}\text { Oud-gedeputeerde en eilandsraadslid. } \\
\text { I2 januari 2016 }\end{array}$ \\
Sabaanse ambtenaar werkzaam bij het Openbaar Lichaam Saba. \\
I3 januari 2016 & Eilandsraadslid voor de Saba Labour Party. \\
I3 januari 2016 & Voormalig eilandsraadslid (2007-20I I). \\
I4 januari 2016 & Eilandsraadslid voor de Windward Islands People's Movement. \\
& Nederlandse ambtenaar werkzaam bij de Rijksdienst Caribisch \\
I4 januari 2016 & Gederland (RCN). \\
I4 januari 2016 & Gedeputeerde in het bestuurscollege. \\
I5 januari 2016 & Nederlandse ambtenaar werkzaam bij de Rijksdienst Caribisch \\
I6 januari 2016 & Nederland (RCN). \\
I8 januari 2016 & Journalist voor een online nieuwsplatform. \\
I9 januari 2016 & Eilandsraadslid voor de Windward Islands People's Movement. \\
\hline
\end{tabular}

Bonaire:

\begin{tabular}{|c|c|}
\hline 28 juni 2016 & Eilandsraadslid voor de Movementu di Pueblo Boneriano. \\
\hline 28 juni 2016 & Hoge publieke functionaris op Bonaire. \\
\hline 30 juni 2016 & Oud-gedeputeerde in het bestuurscollege (2015-2016). \\
\hline 30 juni 2016 & Eilandsraadslid voor de Movementu di Pueblo Boneriano. \\
\hline I juli 2016 & $\begin{array}{l}\text { Leden van een non-governmental organization die zich bezighoudt } \\
\text { met politiek op Bonaire. }\end{array}$ \\
\hline I juli 2016 & $\begin{array}{l}\text { Bonairiaanse ambtenaar werkzaam bij de Rijkdienst Caribisch } \\
\text { Nederland (RCN). }\end{array}$ \\
\hline 2 juli 2016 & Oud-eilandsraadslid van Bonaire (20II-20I5). \\
\hline 4 juli 2016 & Gedeputeerde in het bestuurscollege. \\
\hline 4 juli 2016 & $\begin{array}{l}\text { Bonairiaanse ambtenaar werkzaam bij het Openbaar Lichaam } \\
\text { Bonaire. }\end{array}$ \\
\hline 5 juli 2016 & Onafhankelijk eilandsraadslid. \\
\hline 5 juli 2016 & Journalist werkzaam bij een online nieuwsplatform. \\
\hline 7 juli 2016 & Eilandsraadslid voor de Partido Demokratiko Boneriano. \\
\hline 7 juli 2016 & Eilandsraadslid voor de Partido Demokratiko Boneriano. \\
\hline 7 juli 2016 & Eilandsraadslid voor de Movementu di Pueblo Boneriano. \\
\hline 8 juli 2016 & Onafhankelijk eilandsraadslid. \\
\hline
\end{tabular}

\section{Noten}

1 De verschillende instituties hebben binnen dit model wel enkele andere namen gekregen. In Caribisch Nederland heet de gemeenteraad 'eilandsraad', het college van B\&W wordt 'bestuurscollege' genoemd, wethouders zijn 'gedeputeerden' en de burgermeester is de 'gezaghebber'. In tegenstelling tot gewone Nederlandse 
gemeenten vallen de eilanden bestuurlijk gezien niet onder een Nederlandse provincie.

2 In de analyse zal gebruik worden gemaakt van citaten en quotes uit deze interviews om bepaalde argumenten te illustreren of verduidelijken. Vanwege de kleinschaligheid van de eilanden en de gevoeligheid van het onderwerp is ervoor gekozen om deze quotes te anonimiseren, zodat zij niet naar individuele respondenten te herleiden zijn. Alle gebruikte quotes en citaten zijn representatief voor het gehele interviewmateriaal, tenzij anders is aangegeven.

3 In de Nederlandse context zijn de eilanden qua bevolkingsomvang goed te vergelijken met de Waddeneilanden, die een bevolking hebben van tussen de 13.500 (Texel) en 900 (Schiermonnikoog) inwoners, en daarmee behoren tot de kleinste gemeenten in Europees Nederland.

4 Politricks en democrazy zijn twee woordspelingen die in de Engelstalige Cariben (waaronder Saba en Sint-Eustatius) vaak worden gebruikt om te verwijzen naar politieke spelletjes en de vuile aspecten van politiek.

5 Dit model wordt al sinds 2002 in gewone Nederlandse gemeenten gebruikt en is ingevoerd door middel van de Wet dualisering gemeentebestuur.

6 Onder bestuurswisseling wordt verstaan dat er een verandering is in de samenstelling van de partijen of personen die samen een bestuurlijke meerderheid (coalitie) in de eilandsraad vormen, of een verandering van de gedeputeerden (wethouders).

7 Bij de eilandsraadsverkiezingen van 2015 werd op Bonaire 11,5 procent en op Saba zelfs 21 procent van alle stemmen door middel van een volmacht uitgebracht.

8 Windward Islands People’s Movement.

\section{Literatuur}

Aldrich, R., \& Connell, J. (1998). The Last Colonies. Cambridge: Cambridge University Press.

Anckar, D. (2002). Why are small island states democracies? The Round Table, 365: 375-390.

Anckar, D. (2010). Small is democratic, but who is small? Arts and Social Sciences Journal, 2: 1-10.

Ayisi, E. (1995). St. Eustatius. The Treasure Island of the Caribbean. Trenton, NJ: Africa World Press, Inc.

Baldacchino, G. (2010). Island Enclaves. Offshoring Strategies, Creative Governance, and SubNational Island Jurisdictions. Montréal: McGill-Queen's University Press.

Baldacchino, G. (2012). Islands and despots. Commonwealth and Comparative Politics, 50 (1): 103-120.

Bor, W. van den (1979). Eiland op Drift. De sociale organisatie van een kleine Caribische samenleving: St. Eustatius. Wageningen: Landbouwhogeschool. 
Clegg, P. (2009). Governing the UK Caribbean overseas territories: A two-way perspective. In: P. Clegg \& E. Pantojas-García (red.), Governance in the Non-Independent Caribbean. Kingston: Ian Randle Publishers.

Corbett, J. (2015). Being Political. Leadership and Democracy in the Pacific Islands. Honolulu: University of Hawai'i Press.

Dahl, R.A., \& Tufte, E.R. (1973). Size and Democracy. Stanford, CA: Stanford University Press.

Diamond, L.J., \& Tsalik, S. (1999). Size and democracy: the case for decentralization. In: L.J. Diamond (red.), Developing democracy: towards consolidation. Baltimore, MD: The John Hopkins University Press.

Duncan, N.T., \& Woods, D. (2007). What About Us? The Anglo-Caribbean Democratic Experience. Commonwealth and Comparative Politics, 45 (2): 202-218.

Edie, C. (1994). Democracy in the Caribbean: Myths and Realities. Westport, CT: Praeger.

Erk, J. \& Veenendaal, W. (2014). Is Small Really Beautiful? The Microstate Mistake. Journal of Democracy, 25 (3): 135-148.

Helmke, G., \& Levitsky, S. (2004). Informal Institutions and Comparative Politics: A Research Agenda. Perspectives on Politics, 2 (4): 725-740.

Hinds, D. (2008). Beyond Formal Democracy: The Discourse on Democracy and Governance in the Anglophone Caribbean. Commonwealth and Comparative Politics, 46 (3): 388-406.

Katzenstein, P. (1985). Small States in World Markets. Ithaca: Cornell University Press.

Klomp, A. (1983). Politiek op Bonaire. Utrecht: Instituut voor Culturele Antropologie.

Lauth, H.J. (2000). Informal Institutions and Democracy. Democratization, 7 (4): 21-50.

Lijphart, A. (1977). Democracy in Plural Societies: A Comparative Exploration. New Haven: Yale University Press.

Mamadouh, V., \& Nauta, O. (2002). Bringing democracy to 'The West': Democratic institutions and good governance in the Netherlands Antilles. In: M. de Jong, K. Lalenis \& V. Mamadouh (red.), The Theory and Practice of Institutional Transplantation. Dordrecht: Kluwer Academic Publishers.

Marcha, V., \& Verweel, P. (2003). De cultuur van angst: paradoxale ketenen van angst en zwijgen op Curaçao. Amsterdam: SWP.

Nauta, O. (2015). Vijf jaar Caribisch Nederland: Werking van de nieuwe bestuurlijke structuur. Den Haag.

Oostindie, G., \& Klinkers, I. (2012). Gedeeld Koninkrijk: De ontmanteling van de Nederlandse Antillen en de vernieuwing van de trans-Atlantische relaties. Amsterdam: Amsterdam University Press.

Oostindie, G., \& Sutton, P. (2006). Small Scale and the Quality of Governance. Leiden: KITLV.

Ott, D. (2000). Small is Democratic: An Examination of State Size and Democratic Development. New York: Garland.

Peters, D.C. (1992). The Democratic System in the Eastern Caribbean. New York: Greenwood Press.

Rezvani, D. (2014). Surpassing the Sovereign State: The Wealth, Self-Rule, and Security Advantages of Partially Independent Territories. Oxford: Oxford University Press.

Richards, J. (1982). Politics in Small Independent Communities. Conflict or Consensus? Commonwealth and Comparative Politics, 20 (2): 155-171.

Rijksoverheid (2015). Sint Eustatius onder toezicht Rijk. www.rijksoverheid.nl/actueel/ nieuws/2015/06/10/sint-eustatius-onder-toezicht-rijk.

Roitman, J.V., \& Jordaan, H. (2015). Fighting a Foregone Conclusion. Local Interest Groups, West Indian Merchants, and St. Eustatius 1780 - 1810. Tijdschrift voor Sociale en Economische Geschiedenis, 12 (1): 79-100. 
Ryan, S.D. (1999). Winner Takes All: The Westminster Experience in the Caribbean. St. Augustine, Trinidad and Tobago: UWI Press.

Schrils, J. (1990). Een democratie in gevaar: een verslag van de situatie op Curaçao tot 1987. Assen: Van Gorcum.

Somin, I. (2013). Democracy and Political Ignorance. Why Smaller Government Is Smarter. Stanford: Stanford University Press.

Spies, L., Soons, A., Thodé, G., Verhey, L., \& Weekers, F. (2015). Vijf jaar verbonden: Bonaire, Sint Eustatius, Saba en Europees Nederland. Den Haag.

Srebrnik, H. (2004). Small Island Nations and Democratic Values. World Development, 32 (2): 329-341.

Sullivan, A.E. (2006). Local Lives, Global Stage: Diasporic Experiences and Changing Family Formation Practices on the Caribbean Island of Saba, Netherlands Antilles. Chapel Hill, NC: University of North Carolina.

Sutton, P. (2007). Democracy and good governance in small states. In: E. Kisanga \& S.J. Danchie (red.), Commonwealth Small States: Issues and Prospects. Londen: Commonwealth Secretariat.

Veenendaal, W. (2013). Size and Personalistic Politics: Characteristics of Political Competition in Four Microstates. The Round Table, 102(3), 245-257.

Veenendaal, W. (2014). Politics and Democracy in Microstates. Londen: Routledge.

Veenendaal, W., \& Corbett, J. (2015). Why Small States Offer Important Answers to Large Questions. Comparative Political Studies, 48(4), 527-549.

Veenendaal, W. (2016). The Ties That Bind: Smallness, Nonsovereignty, and Political Reform in St. Eustatius. New West Indian Guide, 90(3-4), 257-279.

Verlaan, J. (2009, 19 september). Vastgoedpenoze strijkt neer op Bonaire. NRC.

Verton, P. (1973). Kiezers en politieke partijen in de Nederlandse Antillen. Oranjestad, Aruba: De Wit. 